\title{
Spatial Organization of the University Network: An European Case-Study
}

\author{
Bolgova E.V. \\ Regional Economy and Development Department \\ Samara State University of Economics \\ Samara, Russia \\ elena_bolgova@rambler.ru
}

\author{
Bolgov S.A. \\ Management and Logistics at Transport Department \\ Samara State Transport University \\ Samara, Russia \\ bolgov@vostok-invest.ru
}

\author{
Kurnikova M.V. \\ Regional Economy and Development Department \\ Samara State University of Economics \\ Samara, Russia \\ mvkurnikova@gmail.com
}

\begin{abstract}
The spatial strategy of the Russian Federation implies the university network development in compliance with the new conditions of economic development, geographic concentration of labour, scientific and technological, innovative activities. For a long time, a geographic aspect has not been addressed while reforming higher education in spite of a lot of research and managerial experience in spatial university distribution worldwide. In this regard, the study is aimed at grounding the prospects for improving spatial university distribution based on the European experience of countries with different educational models. Based on the methodology of the empirical and statistical analysis, rankings, the authors researched into the theoretical backgrounds of university network distribution, the classification of spatial specifics of European educational models, the conditions for the successful adaptation of the European experience in Russia. The novelty of the research is in the working-out of the university network spatial organization based on the case study of countries with different educational models that have been proved successful. The authors used the methodology of empirical, systemic and comparative analysis. Rankings and general purpose and special purpose applications (Microsoft Excel, Statistica 8.0) were used to observe and classify raw data and calculate integrative indicators. The main results of the research could be used for further research into the spatial distribution of economic resources, for strategic planning activities.
\end{abstract}

Keywords-university network; spatial organization; analysis; European case-study.

\section{INTRODUCTION}

The Strategy of the Russian Federation Spatial Development sets out a new framework for national universities associated with the reduction in regional disparities and the improvement of competitive economies of
Russian subjects [1]. order to respond to these requirements, university network spatial distribution needs to be aligned with the economic distribution throughout the country and concentrated labour, scientific and technological, innovative activities. Particular significance is assumed here by the European experience where a university network is arranged throughout the countries and preserves and develops human capital both in the centres of economic growth and small and medium-sized urban areas [2]. The analysis of the European experience in the university network spatial organization in continental European countries and the UK may help substantially in addressing that problem and be used while grounding the prospects for the Russian university network development.

\section{LITERATURE REVIEW}

The studies of the European university networks usually use the binary typology of educational models based on the differences in educational policies in Anglo-Saxon countries and the states in the continental Europe. Referring to the models of higher education, the terms 'Anglo-Saxon' and 'continental' have been applied for the educational models of the countries belonging to a certain linguistic group since the $19^{\text {th }}$ century.

A detailed comparative analysis of the Anglo-Saxon and continental models was carried out by V.S. Vahstain who proved that the continental model is guided by the principle of free access to education while the Anglo-Saxon one is primarily based on a commercial nature and realized by marketing instruments [3]. Most researchers consider that such dissimilar characteristics arise from the role of the government in managing higher education and different levels of university autonomies [4-6]. 
graduates' average wage levels, students' satisfaction with educational results; all higher education programmes are ranked according to bachelor's, master's and doctoral sectors. around the causes of the unfolding trend toward the convergence of those models. The incorporation of the features of the Anglo-Saxon and continental educational models creates a new university model evolving from the variety of approaches: from 'knowledge economy' [7] to 'cluster approach to a university as an educational and scientific centre and a driving force for regional development [8, 9]. G. Goldstein and J. Drucker point out the shift in the traditional university functions (education and research) toward entrepreneurship. This entrepreneurial function consisting in innovative commercialization creates a network cooperation between universities, businesses and government and increases the role of universities in geographic development [10]. H. Etzkowitz presents a spatial interaction between universities, businesses and government as a triplehelix model that is a three-element structure and a managerial tool for providing regional innovative development through an innovative initiative [11]. On the basis of the British experience, Chatterton and Goddard add the function of cooperation with local community (business and local authorities) to the list of classical university functions [12-13]. Kohoutek and Pinheiro stress out the importance of university contribution to the regional economies and the development of their strategies according to the needs of local industrial clusters [14]. Harrison and Turok focus the analysis regional socio-economic development on the specifics of university development and work out econometric methodology for assessing the impact of university research on regional development [15]. Pugh analyses the opportunities of university impact on the economies of underdeveloped and depressive regions [16]. Based on the Israeli case-study, Frenkel and Leck research into spatial aspects of higher education and develop forecasting models for peripheral universities graduates' desirable job opportunities in high-tech industries [17].

The argument for the geographic factor being the key one in the convergence of the Anglo-Saxon and continental educational models determines the significance of the geographical context in the development of higher education and the need to research into the European experience in university network spatial organization.

\section{METHODOLOGY AND METHODS}

The working methodology includes:

1) an empirical analysis of institutional differences between the Anglo-Saxon and continental educational models;

2) a statistical analysis of the geographic distribution of top master's programmes in European countries based on Eduniversal Masters Ranking (Eduniversal). It is a universal platform created by the Paris consulting company to promote academic programmes globally. Their ranking uses a scoring system based on their own interviews and expert assessment. The value of such information source is defined by two factors: the geography of academic programmes under analysis and the list of estimates based on their methodology using the criteria of university publicity and its prestige among employers,

\section{A. An Empirical Study}

The features of the Anglo-Saxon educational model are historically based on the traditions of the British system of higher education. The Anglo-Saxon model is extremely heterogeneous in most institutional features: types of universities, sources of funding, regulations and managerial practices. The types of higher education institutions are defined by generational specifics of higher education in the UK pointed out by V. Vahstein [3], associated with the degree of university prestige.

An important feature of the Anglo-Saxon model is the independence of higher education from state regulation, a large proportion of a commercial sector, the influence of private universities on the institutional framework of the educational market. The degree of the academic freedom of universities is only limited by their economic and marketing characteristics.

According to its institutional features, the Anglo-Saxon model of higher education is traditionally opposed to the continental one typical for Germany, France, Italy, Switzerland, Scandinavian countries. The differences are based on the state control over universities, a stratified access to university education (free of charge as a rule). The state educational policy is based on governments and intergovernmental bodies performing the most of regulation and coordination.

The Humboldtian university model is the foundation for the continental model of higher education with its principles of academic freedom, the cohesion of research and teaching which enables to consider education as an institutional governmental function. Continental universities used to have been connected with government and rarely interacted with market until nowadays. Governments created and financed universities, regulated their activities while business community was only a potential employer of their graduates. Traditionally close integration of universities and governments resulted in the latter, not market, starting reforms in higher education, supporting universities and set rules of competition. However, governmental control does not devalue one of the main features of national university networks of the continental model - their orientation on current developments of countries. This is realized through universities being dynamic in responding to the challenges, risks, practical needs of economy and social sphere in the framework of direct cooperation between business and scientific community through enterprises financing research and the creation of enterprises at the universities.

The European case-study of the university networks spatial organization is conducted according to the following principles:

- considering institutional differences between the Anglo-Saxon and the continental models;

\section{B. A Statistical Research}




\begin{tabular}{|c|c|c|}
\hline Programme & University \\
\hline $\begin{array}{c}\text { Public } \\
\text { Administrati } \\
\text { on }\end{array}$ & $\begin{array}{c}\text { SciencesPo Paris, Paris } \\
\text { Université Paris 1 Panthéon-Sorbonne, Paris } \\
\text { Ecole de Management de Normandie, Cannes } \\
\text { Number of programmes in the ranking - 7 }\end{array}$ \\
\hline \multicolumn{2}{|c|}{ Number of programmes in the ranking } \\
\hline \multicolumn{2}{|c|}{ Incl. Top 3 } \\
\hline Number / per cent of them in Paris out of Top 3 \\
\hline Number / per cent of them in Paris out of the ranking \\
\hline
\end{tabular}

${ }^{a}$ Worked out by the authors according to: Eduniversal best Masters ranking in France, http://www.best-masters.com/ranking-master-in-france.html

39 out of 105 French master's programmes are in Top 3 Eduniversal ranking, 24 of them are being implemented in Paris. The proportion of top-rated programmes of the metropolitan universities amounts to 61.5 per cent of Top 3 programmes, or 22.8 per cent of all programmes included in the ranking. 15 programmes (38.5 per cent) are implemented by universities of the largest French cities: Lyon, Grenoble, Marseille, Toulon, as well as of smaller ones - ClermontFerrand, Cannes.

TABLE II. GEOGRAPHIC DISTRIBUTION OF THE TOP 3 MASTER'S PROGRAMS IN THE EDUNIVERSAL BEST MASTERS RANKING IN GERMANY IN THE 2018/2019 ACADEMIC YEAR ${ }^{A}$

\begin{tabular}{|c|c|}
\hline Programme & University \\
\hline Accounting & $\begin{array}{l}\text { WHU - Otto Beisheim School of Management, } \\
\text { Vallendar } \\
\text { School of Finance \& Management, Frankfurt am } \\
\text { Main } \\
\text { Reutlingen University, Reutlingen } \\
\text { Number of programmes in the ranking - } 3\end{array}$ \\
\hline $\begin{array}{l}\text { Corporate } \\
\text { Finance }\end{array}$ & $\begin{array}{c}\text { Goethe Universität Frankfurt Am Main, Frankfurt am } \\
\text { Main } \\
\text { Frankfurt School of Finance and Management, } \\
\text { Frankfurt am Main } \\
\text { HHL Leipzig Graduate School of Management, } \\
\text { Leipzig } \\
\text { Number of programmes in the ranking - } 3\end{array}$ \\
\hline $\begin{array}{l}\text { Communicat } \\
\text { ions }\end{array}$ & $\begin{array}{c}\text { University of Mannheim, Mannheim } \\
\text { LMU München, München } \\
\text { FH Pforzheim University, Pforzheim } \\
\text { Number of programmes in the ranking - } 3\end{array}$ \\
\hline Marketing & Absent in the ranking \\
\hline $\begin{array}{l}\text { Energy and } \\
\text { Natural } \\
\text { Resources }\end{array}$ & $\begin{array}{c}\text { Frankfurt School of Finance \& Management, } \\
\text { Frankfurt am Main } \\
\text { TU München - School of Forest Science and Resource } \\
\text { Management, München } \\
\text { Humboldt-Universität zu Berlin, Berlin } \\
\text { Number of programmes in the ranking - } 9\end{array}$ \\
\hline $\begin{array}{l}\text { International } \\
\text { Business } \\
\text { Law }\end{array}$ & $\begin{array}{c}\text { University of Mannheim - School of Law and } \\
\text { Economics, Mannheim } \\
\text { WHU - Otto Beisheim School of Management, } \\
\text { Vallendar } \\
\text { Frankfurt School of Finance \& Management, } \\
\text { Frankfurt am Main } \\
\text { Number of programmes in the ranking - } 4\end{array}$ \\
\hline $\begin{array}{l}\text { Industrial } \\
\text { and } \\
\text { Operations } \\
\text { Managemen } \\
\text { t }\end{array}$ & $\begin{array}{l}\text { Reutlingen University, Reutlingen } \\
\text { Rwth Aachen University Fakultät Für } \\
\text { Wirtschaftwissenschaften, Aachen } \\
\text { FH München University, München } \\
\text { Number of programmes in the ranking - } 3\end{array}$ \\
\hline
\end{tabular}




\begin{tabular}{|c|c|c|}
\hline Programme & \multicolumn{2}{|l|}{ University } \\
\hline $\begin{array}{l}\text { Innovation } \\
\text { and Project } \\
\text { Managemen } \\
\mathrm{t}\end{array}$ & \multicolumn{2}{|c|}{$\begin{array}{l}\text { EBS Universität - Business School, Estrich-Winkel } \\
\text { Number of programmes in the ranking - } 1\end{array}$} \\
\hline $\begin{array}{l}\text { International } \\
\text { Managemen } \\
\mathrm{t}\end{array}$ & \multicolumn{2}{|c|}{$\begin{array}{l}\text { WHU - Otto Beisheim School of Management, } \\
\text { Vallendar } \\
\text { University of Cologne - Faculty of Management, } \\
\text { Economics and Social Sciences, Cologne } \\
\text { Reutlingen University - ESB Business School, } \\
\text { Reutlingen } \\
\text { Number of programmes in the ranking - } 4\end{array}$} \\
\hline $\begin{array}{l}\text { Managemen } \\
\mathrm{t}\end{array}$ & \multicolumn{2}{|c|}{$\begin{array}{c}\text { EBS Universität - Business School, Wiesbaden } \\
\text { University of Mannheim, Mannheim } \\
\text { Frankfurt School of Finance \& Management, } \\
\text { Frankfurt am Main } \\
\text { Number of programmes in the ranking - } 7\end{array}$} \\
\hline $\begin{array}{c}\text { Data } \\
\text { Analytics }\end{array}$ & \multicolumn{2}{|c|}{$\begin{array}{l}\text { Frankfurt School of Finance \& Management, } \\
\text { Frankfurt am Main } \\
\text { Technical University of München, München } \\
\text { Number of programmes in the ranking - } 2\end{array}$} \\
\hline $\begin{array}{l}\text { Information } \\
\text { Systems } \\
\text { Managemen } \\
\mathrm{t}\end{array}$ & \multicolumn{2}{|c|}{$\begin{array}{l}\text { University of Mannheim, Mannheim } \\
\text { FH Pforzheim University, Pforzheim } \\
\text { University of Cologne - Faculty of Management, } \\
\text { Economics and Social Sciences, Cologne } \\
\text { Number of programmes in the ranking - } 6\end{array}$} \\
\hline $\begin{array}{c}\text { Public } \\
\text { Administrati } \\
\text { on }\end{array}$ & \multicolumn{2}{|c|}{$\begin{array}{l}\text { Freie Universität (FU) Berlin, Berlin } \\
\text { University of Münster, Münster } \\
\text { Universität Freiburg - Faculty of Economics and } \\
\text { Behavioral Sciences, Freiburg } \\
\text { Number of programmes in the ranking - } 5\end{array}$} \\
\hline Numb & f programmes in the ranking & 50 \\
\hline & Incl. Top 3 & 33 \\
\hline Number / & cent of them in Berlin out of Top 3 & $2 / 6,1$ \\
\hline Number / per & of them in Berlin out of the ranking & $2 / 4,0$ \\
\hline
\end{tabular}

${ }^{\text {a }}$ worked out by the authors according to: Eduniversal best Masters ranking in Germanyhttp://www.best-masters.com/ranking-master-in-germany.html

The uniformity as a principle of geographic organization of university networks in the continental model is the same in Germany. 33 out of 50 German master's programmes are in Top 3 Eduniversal ranking, only 2 of them are being implemented in Berlin (or 6.1 per cent of Top 3 programmes; 4.0 per cent of all programmes included in the ranking). In this country, universities are mainly located not only in large industrial cities, but also in smaller urban areas - traditional and new university centres of the country.

The geographic distribution of Top 3 master's programmes reveals their equal distribution throughout the UK - the country of the Anglo-Saxon model (see Table III).

TABLE III. GEOGRAPHIC DISTRIBUTION OF THE TOP 3 MASTER'S PROGRAMS IN THE EDUNIVERSAL BEST MASTERS RANKING IN THE UK IN THE 2018/2019 ACADEMIC YEAR ${ }^{\text {A }}$

\begin{tabular}{|c|c|}
\hline Programme & University \\
\hline Accounting & LSE - London School of Economics and Political \\
Science, London \\
Warwick Business School - University of Warwick,
\end{tabular}

\begin{tabular}{|c|c|}
\hline Programme & University \\
\hline & $\begin{array}{c}\text { Warwick } \\
\text { Alliance Manchester Business School - The University } \\
\text { of Manchester, Manchester } \\
\text { Number of programmes in the ranking }-14\end{array}$ \\
\hline $\begin{array}{l}\text { Corporate } \\
\text { Finance }\end{array}$ & $\begin{array}{c}\text { London Business School, London } \\
\text { LSE - London School of Economics and Political } \\
\text { Science, London } \\
\text { University of Cambridge, Cambridge } \\
\text { Judge Business School, Cambridge } \\
\text { Number of programmes in the ranking - } 11\end{array}$ \\
\hline $\begin{array}{l}\text { Communicat } \\
\text { ions }\end{array}$ & $\begin{array}{l}\text { LSE - London School of Economics and Political } \\
\text { Science, London } \\
\text { The University of Manchester, Manchester } \\
\text { Imperial College London, London } \\
\text { Number of programmes in the ranking -11 }\end{array}$ \\
\hline Marketing & $\begin{array}{l}\text { Warwick Business School - University of Warwick, } \\
\text { Warwick } \\
\text { Alliance Manchester Business School - The University } \\
\text { of Manchester, Manchester } \\
\text { Cranfield School of Management, Cranfield } \\
\text { Number of programmes in the ranking - } 8\end{array}$ \\
\hline $\begin{array}{l}\text { Energy and } \\
\text { Natural } \\
\text { Resources }\end{array}$ & $\begin{array}{c}\text { University of Oxford, Oxford } \\
\text { University of Edinburgh, Edinburgh } \\
\text { Cranfield University, Cranfield } \\
\text { Number of programmes in the ranking -17 }\end{array}$ \\
\hline $\begin{array}{l}\text { International } \\
\text { Business } \\
\text { Law }\end{array}$ & $\begin{array}{c}\text { University of Oxford, Oxford } \\
\text { University of Cambridge, Cambridge } \\
\text { LSE - London School of Economics and Political } \\
\text { Science, London } \\
\text { Number of programmes in the ranking - } 6\end{array}$ \\
\hline $\begin{array}{l}\text { Industrial } \\
\text { and } \\
\text { Operations } \\
\text { Managemen } \\
\text { t }\end{array}$ & $\begin{array}{l}\text { University of Warwick, Warwick } \\
\text { Aston University, Birmingham } \\
\text { The University of Nottingham, Nottingham } \\
\text { Number of programmes in the ranking - } 5\end{array}$ \\
\hline $\begin{array}{l}\text { Innovation } \\
\text { and Project } \\
\text { Managemen } \\
\text { t }\end{array}$ & $\begin{array}{c}\text { Imperial College London - Dyson School of Design } \\
\text { Engineering, London } \\
\text { Lancaster University, Lancaster } \\
\text { University of Bath School of Management, Bath } \\
\text { Number of programmes in the ranking - } 5\end{array}$ \\
\hline $\begin{array}{l}\text { International } \\
\text { Managemen } \\
\mathrm{t}\end{array}$ & $\begin{array}{l}\text { London Business School, London } \\
\text { LSE - London School of Economics and Political } \\
\text { Science, London } \\
\text { Warwick Business School - University of Warwick, } \\
\text { Warwick } \\
\text { Number of programmes in the ranking - } 14\end{array}$ \\
\hline $\begin{array}{c}\text { Managemen } \\
\mathrm{t}\end{array}$ & $\begin{array}{c}\text { London Business School, London } \\
\text { University of Oxford, Oxford } \\
\text { LSE - London School of Economics and Political } \\
\text { Science, London } \\
\text { Number of programmes in the ranking - } 9\end{array}$ \\
\hline $\begin{array}{c}\text { Data } \\
\text { Analytics }\end{array}$ & $\begin{array}{l}\text { University of Warwick, Warwick } \\
\text { Imperial College London, London } \\
\text { Aston University, Birmingham } \\
\text { Number of programmes in the ranking - } 11\end{array}$ \\
\hline $\begin{array}{l}\text { Information } \\
\text { Systems } \\
\text { Managemen } \\
\text { t }\end{array}$ & $\begin{array}{l}\text { LSE - London School of Economics and Political } \\
\text { Science, London } \\
\text { Warwick Business School - University of Warwick, } \\
\text { Warwick } \\
\text { Aston Business School Birmingham, Birmingham } \\
\quad \text { Number of programmes in the ranking - } 8\end{array}$ \\
\hline $\begin{array}{l}\text { Public } \\
\text { Administrati } \\
\text { on }\end{array}$ & $\begin{array}{l}\text { LSE - London School of Economics and Political } \\
\text { Science, London } \\
\text { University of Oxford, Blavatnik School of government, } \\
\text { Science } \\
\text { The University of Manchester - School of environment, } \\
\text { education and development, Manchester }\end{array}$ \\
\hline
\end{tabular}




\begin{tabular}{|c|c|}
\hline \multirow{2}{*}{ Programme } & \multicolumn{2}{|c|}{ University } \\
\hline & Number of programmes in the ranking - 28 \\
\hline Number of programmes in the ranking & 147 \\
\hline \multicolumn{2}{|c|}{ Incl. Top 3 } \\
\hline Number / per cent of them in London out of Top 3 & $14 / 35,9$ \\
\hline \multicolumn{2}{|c|}{ Number / per cent of them in London out of the } \\
ranking
\end{tabular}

${ }^{\text {a }}$ worked out by the authors according to: Eduniversal best Masters ranking in the United Kingdom: http://www.best-masters.com/ranking-master-in-united-kingdom.html

39 out of 147 British master's programmes belong to Top 3 in the ranking while 14 of them are implemented in London. Thus, the proportion of top-rated programmes of London universities amounts to 35.9 per cent of Top 3 level, or 9.5 per cent of all programmes in the ranking. Thus, 64.1 per cent 25 master's programmes are implemented outside the capital city. The presented distribution reflects high quality of higher education not only in the capital city and historically established and globally well-known university centres, but also in the urban areas of national importance.

\section{RESULTS}

The practical significance of the European experience analysis in the geographic distribution of university networks consists in its comparison with the geographic distribution of top-rated master's programmes in Russia. Such a comparison reveals substantive differences in the geographic distribution of universities in the European countries and Russia and could be used for grounding the prospects for improving spatial organization of the Russian university network (see Table IV).

The analysis reveals that 32 programmes out of 45 master's programmes in the Eduniversal ranking are among Top 3. The proportion of programmes being implemented in Moscow amounts to 65.6 per cent (21 programmes). Outside the capital city, the rest 11 top-rated programmes are implemented in St Petersburg, the second largest city in Russia, in Kazan and Ekaterinburg - Russian industrial centres. Obviously, these four cities of Top 3 master's programmes are indicative of the greatest concentration of the university network and disparities in its geographic distribution.

TABLE VI. GEOGRAPHIC DISTRIBUTION OF THE TOP 3 MASTER'S PROGRAMS IN THE EDUNIVERSAL BEST MASTERS RANKING IN RUSSIA IN THE 2018/2019 ACADEMIC YEAR ${ }^{\text {A }}$

\begin{tabular}{|c|c|}
\hline Programme & University \\
\hline Accounting & $\begin{array}{c}\text { Kazan Federal University Higher School of Business, } \\
\text { Kazan } \\
\text { Number of programmes in the ranking - 1 }\end{array}$ \\
\hline Corporate & $\begin{array}{c}\text { St. Petersburg University, } \\
\text { Finance }\end{array}$ \\
& The Russian Presidential Academy of National \\
& Economy and Public Administration, Moscow \\
& Plekhanov Russian University of Economics - \\
& International Business School (IBS Plekhanov), \\
& Moscow \\
& Number of programmes in the ranking - 6 \\
\hline
\end{tabular}

\begin{tabular}{|c|c|}
\hline Programme & University \\
\hline $\begin{array}{c}\text { Communicatio } \\
\text { ns }\end{array}$ & $\begin{array}{c}\text { St. Petersburg University, St. Petersburg } \\
\text { The Russian Presidential Academy of National } \\
\text { Economy and Public Administration, Moscow } \\
\text { Lomonosov Moscow State University - Faculty of } \\
\text { Philosophy, Moscow } \\
\text { Number of programmes in the ranking - } 3 \\
\end{array}$ \\
\hline Marketing & $\begin{array}{l}\text { The Russian Presidential Academy of National } \\
\text { Economy and Public Administration, Moscow } \\
\text { National Research University Higher School of } \\
\text { Economics - Faculty of Business and Management } \\
\text { (BM HSE), Moscow } \\
\text { Moscow International Higher Business School } \\
\text { MIRBIS (Institute), Moscow } \\
\text { Number of programmes in the ranking - } 4\end{array}$ \\
\hline $\begin{array}{l}\text { Energy and } \\
\text { Natural } \\
\text { Resources }\end{array}$ & $\begin{array}{l}\text { Business School of Ural Federal University named } \\
\text { after the first President of Russia B.N. Yeltsin, } \\
\text { Ekaterinburg } \\
\text { Number of programmes in the ranking - } 1\end{array}$ \\
\hline $\begin{array}{c}\text { International } \\
\text { Business Law }\end{array}$ & $\begin{array}{l}\text { The Russian Presidential Academy of National } \\
\text { Economy and Public Administration, Moscow } \\
\text { St. Petersburg University, } \\
\text { St. Petersburg } \\
\text { Number of programmes in the ranking - } 2\end{array}$ \\
\hline $\begin{array}{c}\text { Industrial and } \\
\text { Operations } \\
\text { Management }\end{array}$ & $\begin{array}{l}\text { St. Petersburg University, St. Petersburg } \\
\text { International Higher Business School MIRBIS } \\
\text { (Institute), Moscow } \\
\text { The Russian Presidential Academy of National } \\
\text { Economy and Public Administration, Moscow } \\
\text { Number of programmes in the ranking - } 4\end{array}$ \\
\hline $\begin{array}{l}\text { Innovation and } \\
\text { Project } \\
\text { Management }\end{array}$ & $\begin{array}{l}\text { The Russian Presidential Academy of National } \\
\text { Economy and Public Administration, Moscow } \\
\text { National Research University Higher School of } \\
\text { Economics - Faculty of Business and Management } \\
\text { (BM HSE), Moscow } \\
\text { International Higher Business School MIRBIS } \\
\text { (Institute), Moscow } \\
\text { Number of programmes in the ranking - } 5\end{array}$ \\
\hline $\begin{array}{l}\text { International } \\
\text { Management }\end{array}$ & $\begin{array}{l}\text { Graduate School of Management, St. Petersburg } \\
\text { University, St. Petersburg } \\
\text { The Russian Presidential Academy of National } \\
\text { Economy and Public Administration, Moscow } \\
\text { Plekhanov Russian University of Economics - } \\
\text { International Business School (IBS Plekhanov), } \\
\text { Moscow } \\
\text { Number of programmes in the ranking - } 4\end{array}$ \\
\hline Management & $\begin{array}{l}\text { Graduate School of Management, St. Petersburg } \\
\text { University, St. Petersburg } \\
\text { The Russian Presidential Academy of National } \\
\text { Economy and Public Administration, Moscow } \\
\text { National Research University Higher School of } \\
\text { Economics - Faculty of Business and Management } \\
\text { (BM HSE), Moscow } \\
\text { Number of programmes in the ranking - } 6\end{array}$ \\
\hline Data Analytics & $\begin{array}{l}\text { Lomonosov Moscow State University, Moscow } \\
\text { National Research University Higher School of } \\
\text { Economics (BM HSE), Moscow } \\
\text { Business School of Ural Federal University named } \\
\text { after the first President of Russia B.N.Yeltsin, } \\
\text { Ekaterinburg } \\
\text { Number of programmes in the ranking - } 4\end{array}$ \\
\hline $\begin{array}{l}\text { Information } \\
\text { Systems } \\
\text { Management }\end{array}$ & $\begin{array}{c}\text { Lomonosov Moscow State University Business } \\
\text { School, Moscow } \\
\text { Graduate School of Management, St. Petersburg } \\
\text { University, St. Petersburg } \\
\text { Number of programmes in the ranking - } 2\end{array}$ \\
\hline $\begin{array}{c}\text { Public } \\
\text { Administration }\end{array}$ & $\begin{array}{l}\text { St. Petersburg University, St. Petersburg } \\
\text { The Russian Presidential Academy of National } \\
\text { Economy and Public Administration, Moscow } \\
\text { Lomonosov Moscow State University, Moscow } \\
\text { Number of programmes in the ranking - } 3\end{array}$ \\
\hline
\end{tabular}




\begin{tabular}{|c|c|}
\hline Programme & \multicolumn{2}{|c|}{ University } \\
\hline Number of programmes in the ranking & 32 \\
\hline Incl. Top 3 & $21 / 65,6$ \\
\hline Number / per cent of them in Moscow out of Top 3 & $21 / 46,7$ \\
\hline \multicolumn{2}{|c|}{ Number / per cent of them in Moscow out of the } \\
ranking
\end{tabular}

a worked out by the authors according to Eduniversal best Masters ranking in Russia: http://www.best-masters.com/ranking-master-in-russia.html

\section{CONCLUSION}

The European case-study revealed the uniformity in the geographic distribution of top ranked master's programmes throughout all countries of different educational models. Theoretical relevance of the research is in the validation of the hypothesis on the convergence of higher education models. Being a common feature for both models, such uniformity points to the need for improving spatial organization of the Russian university network. The most concentration of Top 3 master's programmes in Moscow and insignificant number of those in St Petersburg, Kazan and Ekaterinburg reveals an excessive concentration of universities in the capital region, in a small number of largest agglomerations. Such a geographic distribution does not fully correspond with the needs of regional well-balanced sustainable development through the efficient geographic distribution of economic resources.

Based on the European experience, in order to improve the geographic organization of the Russian university network, it is necessary to broaden the 'geography of economic growth' through:

- university cooperation with business and regional governments based on triple helix model and its initiative realization. This direction is guaranteed by the plan of launching 15 world-class research and educational centres, competence centres of economic growth [1];

- priority state support of universities enabling the development of high-tech and knowledge-based industries;

- national and regional technological initiative provided by universities, the creation of research and technology centres as elements of the innovative infrastructure of the Russian subjects;

- strategic planning of the university network development within large and largest urban agglomerations, small and medium-sized urban areas, rural territories.

\section{References}

[1] The Decree of the Russian Government "On the approval of the Strategy of spatial development until 2025” No. 207-p dated February 13, 2019.

[2] O.G. Lebedinskaya, A.G. Timofeev, and M.V. Kurnikova, "Developing the mechanism to identify directions of innovative activities for further development”, European Proceedings of Social and Behavioural Sciences, 2019, Vol. 59, pp. 198-205. 10.15405/epsbs.2019.04.23

[3] V. S. Vahshtein, "Two models of educational systems: continental and Atlantic", available at: http://www.intelros.ru/pdf/prognosis/321352_vahshtain.pdf (access date: 19.05.2018).

[4] M. V. Larionova, Topical issues of education development in OECD countries, Moscow, Izdatel'skii dom GU VShE, 2005, 152 p.

[5] M. Dobbins, and Ch. Knill, "Higher Education Governance in France, Germany, and Italy: Change and Variation in the Impact of Transnational Soft Governance”, Policy and Society, 2017, vol. 36, iss. 1, pp. 67-88.

[6] J. Huisman, P. Maassen, and G. Neave (Eds), "Higher Education and the Nation State. The International Dimension of Higher Education", Amsterdam, Elsevier, 2001, pp. 13-73.

[7] M.K. McLendon, and E.C. Ness, "The Politics of State Higher Education Governance Reform”, Peabody Journal of Education, 2003, vol. 78, iss. 4, pp. 66-88.

[8] E.V. Bolgova, and M.V. Kurnikova, "Modelling the spatial organization of the higher education system in the regional economy", Contributions to Economics, 2019, DOI: 10.1007 / 978-3-030-11754-2_4.

[9] E.V. Bolgova, G.N. Grodskaya, and M.V. Kurnikova, "The model for meeting digital economy needs for higher education programs", Advances in Intelligent Systems and Computing, 2020, DOI: 10.1007 / 978-3-030-11367-4_54.

[10] H. Goldstein, and J. Drucker, "The Economic Development Impacts of Universities on Regions: Do Size and Distance Matter?", Economic Development Quarterly, Vol. 20, No. 1, February 2006, pp. 22-43.

[11] H. Etzkowitz, "Incubation of incubators: innovation as a triple helix of university-industry-government networks”, Science and Public Policy, 2002, Vol. 29, Is. 2, 1 April 2002, pp. 115-128.

[12] J. Goddard, and P. Chatterton, "Regional Development Agencies and the knowledge economy: harnessing the potential of universities", Environment and Planning, Government and Policy, 1999, Vol. 17, pp. 685-699.

[13] P. Chatterton, and J. Goddard, "The Response of Higher Education Institutions to Regional Needs", European Journal of Education, 2000, Vol. 35, No. 4, pp. 475-496.

[14] J. Kohoutek, and R. Pinheiro, The Role of Higher Education in the Socio-Economic Development of Peripheral Regions, Higher Education Policy, 2017.

[15] J. Harrison, and I. Turok, "Universities, knowledge and regional development”, Regional Studies, 2017, Vol. 51, No. 7, pp. 977-981.

[16] R. Pugh, "Universities and economic development in lagging regions: ‘Triple helix’ policy in Wales”, Regional Studies, 2016.

[17] A. Frenkel, and E. Leck, Spatial aspects of education - job matching and job selection in Israel, Regional Studies, Samuel Neaman Institute for Advanced Studies in Science and Technology, 2014, URL: http://pickme.carloalberto.org/images/PICKWP54.

[18] Aleksandr S. Kuznetsov. Russian Professor's meeting. Russian Journal of Physical Education and Sport. Pp. 2019, 14(1), 17-22. DOI: 10.14526/2070-4798-2019-14-1-18-24

[19] Kim-Kimen A. N., Kuznetsova Z.M. The development of the traditions of ancestors to the glory of the Yakut sports. 2018, 13(2), pp. 119-123. DOI: $10.14526 / 02 \_2018 \_319$ 